\title{
Application of the logistic model to describe the growth curve in dogs of different breeds
}

\author{
Aplicación del modelo logístico para describir la curva de \\ crecimiento en perros de diferentes razas
}

\begin{abstract}
Sandra Posada O, ${ }^{1 *}$ Ph.D, Luis Gomez O, ${ }^{2}$ M.Sc, Ricardo Rosero N, ${ }^{1}$ Ph.D.
${ }^{1}$ Universidad de Antioquia, Faculty of Agricultural Sciences, Animal Science Research Group-GRICA, AA 1226, Medellin, Colombia. ${ }^{2}$ Empresa Solla S.A., AA 1272, Medellin, Colombia. *Correspondence: slposada@gmail.com.
\end{abstract}

Received: February 2013; Accepted: August 2013.

\begin{abstract}
Objective. To model the growth in dogs of different size and breeds that during their development showed a relative body weight according to the standards of their racial group. Materials and methods. The data used were obtained from the Canine Research Center (CIC), property of Empresa Solla S.A., located in the municipality of Rionegro (Antioquia, Colombia). The parameters of the growth curve were defined based on the logistic model using the procedure PROC NLIN of the SAS. Results. The adult weight (a) ranged from $2.12 \mathrm{Kg}$ (York Shire Terrier) to $32.88 \mathrm{Kg}$ (Weimaraner). For small, medium and large breeds, growth rates $(1 / \mathrm{b})$ during the exponential phase ranged between 9.91$18.91 \%, 9.12-13.83 \%$ and, $8.17-14.38 \%$, respectively, and the average age at which $50 \%$ of the adult weight was reached $\left(x_{0}\right)$ was $3.49 \pm 0.03,4.21 \pm 0.42$ y $5.27 \pm 0.86$ months, correspondingly. Large dog breeds reached maturity $\left(T_{99}\right)$ later than smaller breeds, $14.37 \pm 1.79$ vs. $9.46 \pm 1.63 \mathrm{mo}$. Conclusions. The logistic model was able to describe the growth in dogs of different size, however, a larger sample size will improve its predictive ability, given the individual variability that characterizes growth.
\end{abstract}

Key words: Body size, body weight, growth model, growth rate, regression analysis (Source: $C A B$, USDA).

\section{RESUMEN}

Objetivo. Modelar el crecimiento en perros de diferentes tamaños y razas, que durante su desarrollo exhibieron un peso corporal relativo acorde con los estándares de su grupo racial. Materiales y métodos. Los datos utilizados fueron obtenidos del Centro de Investigaciones Caninas (CIC) de la Empresa Solla S.A., ubicada en el municipio de Rionegro (Antioquia, Colombia). Los parámetros de la curva de crecimiento fueron definidos desde el modelo logístico utilizando el procedimiento PROC NLIN del programa estadístico SAS. Resultados. El peso de los adultos (a) fluctuó entre $2.12 \mathrm{Kg}$ (York Shire Terrier) hasta $32.88 \mathrm{Kg}$ (Weimaraner). Para las razas pequeñas, medianas y grandes, las tasas de crecimiento $(1 / \mathrm{b})$ durante la fase exponencial fluctuaron entre $9.91-18.91 \%, 9.12-13.83 \%$ 
$y, 8.17-14.38 \%$, respectivamente, y la edad media a la cual se alcanzó el $50 \%$ del peso adulto $\left(x_{0}\right)$ fue $3.49 \pm 0.03,4.21 \pm 0.42$ y $5.27 \pm 0.86$ meses, correspondientemente. Las razas de perros grandes alcanzaron la madurez $\left(T_{99}\right)$ mucho más tarde que las razas de perros pequeños, $14.37 \pm 1.79$ vs. $9.46 \pm 1.63$ meses. Conclusiones. El modelo logístico fue adecuado para describir el crecimiento en perros de diferente tamaño, no obstante, un tamaño de muestra mayor mejoraría la capacidad predictiva del mismo, dada la variabilidad individual que caracteriza el crecimiento.

Palabras clave: Análisis de regresión, modelo de crecimiento, peso corporal, tamaño corporal, tasa de crecimiento (Fuente: CAB, USDA).

\section{INTRODUCCIÓN}

El crecimiento es un proceso complejo de proliferación celular en el cual existen interacciones entre la genética, la nutrición y otras influencias ambientales. La medida de crecimiento más usual es el peso corporal, por lo cual el crecimiento puede resumirse a través de modelos matemáticos que se traducen en curvas de ganancia acumulativa de peso (1). Los perros en crecimiento progresan a través de tres períodos críticos en los primeros 12 meses de vida, a saber, un período de lactancia, un período de destete y un período posdestete: éste último que resulta crítico para el desarrollo esquelético y de otros sistemas corporales. En relación con la edad, el crecimiento más rápido se presenta durante los primeros 3-6 meses de vida, en tanto que la madurez (tamaño adulto) se alcanza entre los 1016 meses para las razas grandes y entre los 6-12 meses para las razas más pequeñas, momento en que la mayoría de los de perros han aumentado su peso al nacer entre 40 y 50 veces (2). Dependiendo de la raza, el peso corporal adulto varía más de 100 veces, desde 2-6 lb en la raza Chihuahua hasta 150$180 \mathrm{lb}$ en la raza San Bernardo (3).

Durante el crecimiento resulta esencial aportar una dieta equilibrada para que el animal presente un adecuado desarrollo esquelético y muscular, exhiba la velocidad típica de crecimiento de los ejemplares de su raza y alcance un tamaño adulto normal. De acuerdo con el NRC (4), los perros en crecimiento, por unidad de peso corporal requieren el doble de la energía requerida por los perros adultos de la misma raza. Una disminución en el aporte energético a 1.6 y 1.2 veces el nivel de mantenimiento se recomienda cuando se alcanza el $50 \%$ y $80 \%$ del peso adulto, respectivamente. No obstante, en concepto de Case et al (2) y Hawthorne et al (3), las demandas energéticas están afectadas por variaciones en el tamaño, conformación corporal, temperamento y tipo de pelaje, lo cual genera diferencias en los patrones de crecimiento de razas específicas. Aumentos en la velocidad de crecimiento conducen a madurez precoz, inadecuado desarrollo esquelético, aumento del número de células grasas, mayor riesgo de obesidad en la edad adulta y reducción en la longevidad (5).

\section{INTRODUCTION}

Growth is a complex process of cell proliferation in which there are interactions between genetics, nutrition, and other environmental influences. The most usual growth measurement is body weight, whereupon growth can be summarized through mathematical models that translate into cumulative weight gain curves (1). Growing dogs go through three critical periods in the first 12 months of life, namely, a lactation period, a weaning period and a post-weaning period: the latter is critical for skeletal development and other body systems. In relation to age, the fastest growth occurs during the first 3-6 months of life, while maturity (adult size) is reached between 1016 months for large breeds and between 6-12 months for smaller breeds, at which time most of the dogs have increased their weight at birth in between 40 and 50 times (2). Depending on the breed, adult body weight varies more than 100 times, from 2-6 lb. for Chihuahuas up to 150-180 lb. for St. Bernards (3).

During growth, it is essential to provide a balanced diet so the animal shows proper skeletal and muscular development and the typical growth rate of the specimens of its breed and reaches its normal adult size. According to the NRC (4), growing dogs require twice the energy required by adult dogs of the same breed per unit of body weight. A decrease in the energy contribution to 1.6 and 1.2 times the maintenance level is recommended when $50 \%$ and $80 \%$ of the adult weight is reached, respectively. However, in the opinion of Case et al (2) and Hawthorne et al (3), the energy demand is affected by variations in the size, corporal estructure, temperament and coat type, which generates differences in the growth patterns of specific breeds. Increases in the growth rate lead to an early maturity, inadequate skeletal development, increase in the number of fat cells, increased risk of obesity in adulthood and the reduction of longevity (5). 
El modelo logístico expresa analíticamente el fenómeno de crecimiento de los organismos. Tanto la población humana como la animal encuentran obstáculos de sobrevivencia, los que aumentan proporcionalmente con relación al exceso de la población total. Esto significa que después de un crecimiento acelerado de la población sobreviene siempre un período de avance más lento, que finalmente tiende a estabilizarse (6). Aplicado a los modelos no lineales, la curva logística modela la función sigmoidea, donde el crecimiento inicialmente es exponencial (aumenta en un constante porcentual en función del tiempo), transcurrido un determinado tiempo se ralentiza (la tasa de crecimiento disminuye) y finalmente, en la madurez, se detiene.

Poca información está disponible sobre los parámetros que definen las curvas de crecimiento de razas específicas, lo cual podría orientar al personal responsable de la tenencia de mascotas (criadores, propietarios, profesionales) sobre el ritmo de crecimiento objetivo al que deben dirigir el nivel de alimentación y actividad del animal, que propenda por su salud y bienestar en la edad adulta. El objetivo del presente trabajo fue aplicar el modelo logístico para describir los parámetros de crecimiento de perros de diferentes razas, pequeñas, medianas y grandes, que durante su desarrollo presentaron adecuado peso corporal relativo y condición corporal.

\section{MATERIALES Y MÉTODOS}

Sitio de estudio. Los datos utilizados para la construcción de las curvas de crecimiento fueron obtenidos del Centro de Investigaciones Caninas (CIC) de la Empresa Solla SA, ubicada en el municipio de Rionegro, oriente del departamento de Antioquia (Colombia). Las condiciones agroecológicas de la zona corresponden a una temperatura promedio de $17^{\circ} \mathrm{C}$, humedad relativa del $75 \%$, precipitación anual de $2280 \mathrm{~mm}$ y altura sobre el nivel del mar de $2125 \mathrm{~m}$.

Animales. Perros $(n=21)$, correspondientes a 10 razas diferentes, clasificadas como pequeñas $(n=3)$, medianas $(n=7)$ y grandes $(n=11)$ fueron incluidos en este estudio. Para cada raza, la información correspondiente al número de individuos evaluados, el rango de edad de aplicación del modelo y el número de datos usados para la modelación se presenta en la tabla 1.

Alimentación y manejo. Los animales fueron alimentados con una variedad de alimentos comercialmente disponibles, nutricionalmente completos, de las categorías Premium y Super Premium, y formulados para cumplir con las exigencias nutricionales de la etapa de crecimiento.
The logistic model expresses the growth phenomenon of organisms analytically. Both the animal and human population face obstacles to survival, which increase proportionally in relation to the excess of the total population. This means that after a period of rapid growth in the population there is always a period of slower progress, which finally tends to stabilize (6). Applied to nonlinear models, the logistic curve models the sigmoid function, where growth is initially exponential models (increases by a constant percentage depending on time), and after certain time slows down (growth rate decreases) and finally, in maturity, stops.

Little information is available on the parameters that define the growth curves of specific breeds, which could guide the personnel responsible for the ownership of pets (breeders, owners, professionals) on the target growth rate at which the feeding and activity level of the animal should be directed, for improving their health and wellbeing in adulthood. The objective of this study was to apply the logistic model to describe the growth parameters of dogs of different breeds, small, medium and large, that during their development displayed adequate relative body weight and body condition.

\section{MATERIALS AND METHODS}

Study site. The data used for the construction of the growth curves were obtained from the Canine Research Center (CIC) of Empresa Solla S.A., located in the municipality of Rionegro, to the east of the department of Antioquia (Colombia). The agro-ecological conditions in the area correspond to an average temperature of $17^{\circ} \mathrm{C}$, relative humidity of $75 \%$, annual precipitation of $2280 \mathrm{~mm}$ and height above sea level of $2125 \mathrm{~m}$.

Animals. Dogs $(n=21)$, corresponding to 10 different breeds, classified as small $(n=3)$, medium $(n=7)$ and large $(n=11)$, were included in this study. For each breed, the information corresponding to the number of individuals evaluated, the age range for the application of the model and the number of data used for modeling is shown in table 1 .

Feeding and handling. The animals were fed with a variety of commercially available, nutritionally complete foods of Premium and Super Premium categories, formulated to meet the nutritional demands of the growth stage. The variety of foods offered is because 
Table 1. General characteristics of dog breeds under study.

\begin{tabular}{|c|c|c|c|c|c|}
\hline Size & Breed & PA & NA & ND & Age range $^{1}$ \\
\hline Small & $\begin{array}{l}\text { York Shire Terrier } \\
\text { French Poodle (Toy) }\end{array}$ & $\begin{array}{c}2-3.2 \\
3.2-3.8\end{array}$ & $\begin{array}{c}1 * \\
2 * *\end{array}$ & $\begin{array}{l}34 \\
62\end{array}$ & $\begin{array}{l}17.71-87.57 \\
14.57-77.86\end{array}$ \\
\hline Medium & $\begin{array}{l}\text { Fox Terrier } \\
\text { Teckel } \\
\text { Basset Hound } \\
\text { Beagle }\end{array}$ & $\begin{array}{c}7-8 \\
8-10 \\
11-25 \\
9-14\end{array}$ & $\begin{array}{c}2 * \\
1 * \\
2 * * \\
2 *\end{array}$ & $\begin{array}{c}56 \\
58 \\
108 \\
62\end{array}$ & $\begin{array}{c}9.57-83.71 \\
20.57-156.57 \\
8.14-125.00 \\
23.00-135.86\end{array}$ \\
\hline Large & $\begin{array}{l}\text { Golden retriever } \\
\text { Labrador retriever } \\
\text { Weimaraner } \\
\text { German Shepherd }\end{array}$ & $\begin{array}{l}25-32 \\
25-35 \\
25-38 \\
22-34\end{array}$ & $\begin{array}{c}1 * * \\
4 * * \\
2 * \\
4 * \\
\end{array}$ & $\begin{array}{c}34 \\
231 \\
64 \\
193 \\
\end{array}$ & $\begin{array}{c}12.29-82.14 \\
16.29-152.29 \\
11.29-128.71 \\
4.14-121.00 \\
\end{array}$ \\
\hline
\end{tabular}

PA: Corresponding to the adult weight reported for the breed, not that estimated in this study (7).

NA: Number of animals belonging to each racial group.

ND: Number of data considered for the modeling of each racial group.

${ }^{1}$ Corresponding to the initial and final age (weeks) at which each racial group was weighted.

* Males, **Females.

La variedad de alimentos ofertada obedece a que los ejemplares del CIC deben ser entrenados para la realización de pruebas de palatabilidad. La cantidad suministrada fue individualizada, de acuerdo con el peso corporal y los requerimientos energéticos (4), y garantizada dos veces por día, a las 8 y 18 horas, en los caniles asignados a cada animal.

A partir de las 17 horas, y hasta las 9 horas del día siguiente, los animales fueron alojados en caniles de $2 \times 4 \mathrm{~m}$, que disponían de cubierta superior (techo) en las zonas de alimentación y descanso y de un área al aire libre para la actividades de descanso y excreción. Una vez ofertada la primera ración, los animales fueron organizados en tres grupos, previo estudio y observación de su estructura jerárquica, y ubicados en espacios abiertos, en los cuales socializaban. Igualmente, los animales tuvieron acceso a un espacio adecuado para su entrenamiento (agility), actividad que cada animal practicó de acuerdo con los criterios de un experto, teniendo en cuenta la edad y el nivel de experiencia. Finalmente, cada animal realizaba paseos con duración promedio de una hora, dos veces por semana.

Colecta de información y procesamiento de datos. Los pesajes de cada ejemplar se realizaron con una frecuencia quincenal, siempre en el mismo horario y antes de la oferta de la primera ración diaria. La edad de cada animal fue calculada, previo registro de la fecha de nacimiento, para construir la base de datos peso-edad.

Para cada raza, los parámetros de la curva de crecimiento fueron definidos a partir del modelo logístico descrito por Hawthorne et al (3), correspondiente a:

$y=a /\left\{1+\exp \left[-\left(x-x_{0}\right) / b\right]\right\}$, donde,

$y=$ peso corporal alcanzado a la edad $x$,

$a=$ peso corporal adulto (peso asintótico) (gramos), $(1 / b)=$ tasa de crecimiento durante la fase exponencial (\%) y

$x_{o}=$ tiempo necesario para alcanzar el $50 \%$ del peso adulto (semanas). the specimens of the CIC must be trained for carrying out palatability tests. The quantity supplied was individualized, based on the body weight and energy requirements (4), and guaranteed twice per day, every 8 and 18 hours, in the kennels assigned to each animal.

From 5 p.m. and until 9 a.m. of the next day, the animals were kept in $2 \times 4$ m kennels, which had a top cover (roof) in the feeding and leisure areas and outdoor area for rest and excretion activities. Once the first ration has been offered, the animals were organized into three groups, prior study and observation of their hierarchical structure, and located in open spaces, in which they socialized. Likewise, the animals had access to adequate space for their training (agility), an activity that each animal practiced according to an expert's criteria, taking into account the age and experience level. Finally, each animal made walks with an average duration of one hour, twice a week.

Collection of information and data processing. The weighing of each specimen was made with a weekly frequency, always at the same time and before the first daily ration. The age of each animal was calculated, after the record of the date of birth, to build the weight-age database.

For each breed, the parameters of the growth curve were defined based on the logistic model described by Hawthorne et al (3), corresponding to:

$y=a /\left\{1+\exp \left[-\left(x-x_{0}\right) / b\right]\right\}$, where,

$y=$ body weight reached at age $x$, $a=$ adult body weight (asymptotic weight) (grams),

$(1 / b)=$ growth rate during exponential phase $(\%)$, and

$x_{0}=$ time needed for reaching $50 \%$ of adult weight (weeks). 
El ajuste de los datos a este modelo y las estimativas de los parámetros se realizaron a través de un proceso iterativo usando el algoritmo Marquardt del procedimiento para modelos no lineales PROC NLIN de SAS (8). Todos los ejemplares pertenecientes a una misma raza fueron considerados para ajustar el modelo. Toda vez que la función logística no puede calcular el peso corporal adulto, la edad (semanas) a la cual cada raza alcanzó el $99 \%$ de su peso adulto $\left(T_{99}\right)$ fue calculada a partir de los parámetros estimados.

\section{RESULTADOS}

Las curvas de crecimiento estimadas desde el modelo logístico para cada una de las razas, pequeñas, medianas y grandes se presentan en la figura 1.

Las estimativas de los parámetros, resultantes del ajuste de los datos peso-edad al modelo de crecimiento no lineal, con sus respectivos errores estándar (EE), son presentadas en la tabla 2. El peso adulto (a) fluctuó entre $2.12 \mathrm{Kg}$ (York Shire Terrier) hasta $32.88 \mathrm{Kg}$ (Weimaraner). El $50 \%$ del peso adulto se alcanzó a las $15.11 \pm 0.14,18.26 \pm 1.82$ y $22.85 \pm 3.74$ semanas $\left(x_{0}\right)$ en las razas pequeñas, medianas y grandes, respectivamente. La duración de esta fase de crecimiento se incrementó en proporción con el peso adulto y durante la misma, las tasas de crecimiento fueron exponenciales (el logaritmo del peso corporal incremento linealmente). Las tasas de crecimiento durante la fase exponencial (tasa de incremento de peso por semana) $(1 / b)$ fluctuaron entre 9.91 y $18.91 \%$ para las razas pequeñas, 9.12 y $13.83 \%$ para las medianas y 8.18 y $14.38 \%$ para las grandes. Se observó que las razas pequeñas alcanzaron el $99 \%$ de su peso corporal adulto $\left(T_{99}\right)$ entre las 36 y 46 semanas, las medianas entre la62s 52 y 58 semanas y las grandes entre las 52 y 70 semanas. Finalmente, los coeficientes de determinación $\left(R^{2}\right)$ para todas las razas evaluadas fluctuaron entre 44.49 y $98.80 \%$.
The adjustment of the data to this model and the estimates of parameters were carried out through an iterative process using the Marquardt algorithm of the procedure for nonlinear models PROC NLIN of SAS (8). All the specimens belonging to a same breed were considered for adjusting the model. Whenever the logistic function cannot calculate the adult body weight, the age (weeks) at which each breed reached $99 \%$ of their adult weight $\left(T_{99}\right)$ was calculated from the estimated parameters.

\section{RESULTS}

The growth curves estimated from the logistic model for each of the breeds, small, medium and large are shown in figure 1.

The estimates of the parameters, resulting from the adjustment of the weight-age data to the non-linear growth model, with the respective standard errors (EE), are shown in table 2 . The adult weight (a) ranged between $2.12 \mathrm{Kg}$ (York Shire Terrier) to $32.88 \mathrm{Kg}$ (Weimaraner). Fifty percent of the adult weight was reached at $15.11 \pm 0.14,18.26 \pm 1.82$ and $22.85 \pm 3.74$ $\left(x_{0}\right)$ weeks in small, medium and large breeds, respectively. The duration of this growth phase was increased in proportion to the adult weight and during the same, the growth rates were exponential (the body weight logarithm increased linearly). Growth rates during the exponential phase (weight increase rate per week) $(1 / b)$ fluctuated between 9.91 and $18.91 \%$ for small breeds, 9.12 and $13.83 \%$ for medium-sized breeds, and 8.18 and $14.38 \%$ for large breeds. It was noted that small breeds reached $99 \%$ of their adult body weight $\left(T_{99}\right)$ between 36 and 46 weeks, medium breeds between 52 and 58 weeks and large breeds between 52 and 70 weeks. Finally, the coefficients of determination $\left(R^{2}\right)$ for all breeds evaluated fluctuated between 44.49 and $98.80 \%$.
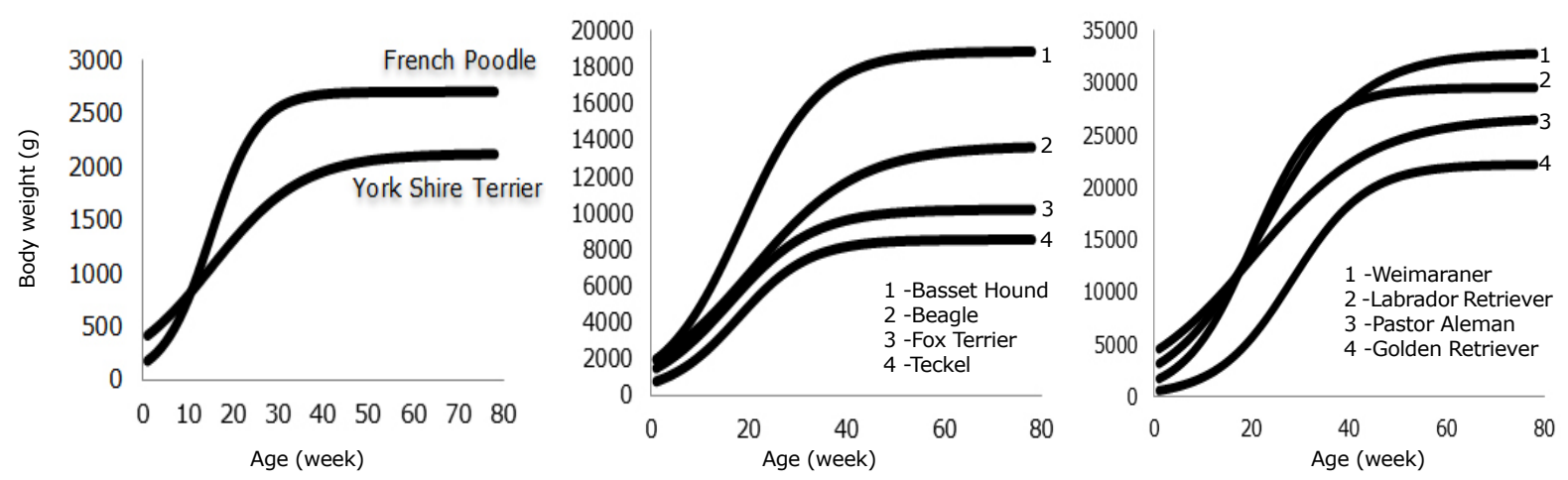

Figure 1. Growth curves estimated by the logistic model for the different breeds under study. 
Table 2. Growth parameters for dogs of different breeds from the logistic model.

\begin{tabular}{|c|c|c|c|c|c|c|}
\hline \multirow{2}{*}{ Size and breed } & \multicolumn{5}{|c|}{ Parameters } & \multirow{2}{*}{$\mathbf{R}^{2}$} \\
\hline & $a(g)$ & $\boldsymbol{b}$ & $1 / b(\%)$ & $x_{o}$ (weeks) & $T_{99}$ (weeks) & \\
\hline Small & & & & & & \\
\hline $\begin{array}{l}\text { York Shire Terrier } \\
\text { French Poodle (Toy) }\end{array}$ & $\begin{array}{l}2124.10(21.43)^{1} \\
2706.60(29.41)\end{array}$ & $\begin{array}{c}10.09(1.13) \\
5.29(0.73)\end{array}$ & $\begin{array}{c}9.91 \\
18.91\end{array}$ & $\begin{array}{l}15.21(1.09) \\
15.01(0.69)\end{array}$ & $\begin{array}{l}46 \\
36\end{array}$ & $\begin{array}{l}92.65 \\
80.73\end{array}$ \\
\hline $\begin{array}{l}\text { Medium } \\
\text { Fox Terrier } \\
\text { Teckel } \\
\text { Basset Hound } \\
\text { Beagle }\end{array}$ & $\begin{array}{c}10191.60(80.87) \\
8537.00(43.83) \\
18873.20(519.70) \\
13677.10(101.00)\end{array}$ & $\begin{array}{c}8.53(0.46) \\
7.23(1.10) \\
8.13(2.09) \\
10.96(1.03)\end{array}$ & $\begin{array}{c}11.72 \\
13.83 \\
12.30 \\
9.12\end{array}$ & $\begin{array}{l}16.12(0.38) \\
17.86(1.25) \\
18.55(1.93) \\
20.52(1.07)\end{array}$ & $\begin{array}{l}54 \\
53 \\
52 \\
58\end{array}$ & $\begin{array}{l}96.97 \\
72.05 \\
44.49 \\
90.22\end{array}$ \\
\hline $\begin{array}{l}\text { Large } \\
\text { Golden Retriever } \\
\text { Labrador Retriever } \\
\text { Weimaraner } \\
\text { German Shepherd } \\
\end{array}$ & $\begin{array}{l}22219.50(216.20) \\
29537.00(121.70) \\
32877.40(186.30) \\
26689.70(371.20)\end{array}$ & $\begin{array}{c}7.62(0.38) \\
6.96(0.48) \\
9.75(0.39) \\
12.23(1.15)\end{array}$ & $\begin{array}{c}13.13 \\
14.38 \\
10.26 \\
8.18 \\
\end{array}$ & $\begin{array}{l}28.17(0.40) \\
20.26(0.69) \\
22.74(0.33) \\
20.23(1.03)\end{array}$ & $\begin{array}{l}61 \\
52 \\
66 \\
70 \\
\end{array}$ & $\begin{array}{l}98.80 \\
71.46 \\
98.54 \\
75.53 \\
\end{array}$ \\
\hline
\end{tabular}

${ }^{1}$ Values corresponding to the average $\pm \mathrm{EE}, a=$ adult body weight (grams), $(1 / b)=$ exponential growth rate (percentage), $x_{0}=$ time necessary to reach $50 \%$ of adult weight (weeks), $T_{99}=$ time necessary to reach $99 \%$ of adult weight (weeks), $\mathrm{R}^{2}=$ coefficient of determination.

\section{DISCUSIón}

La curva logística modela la función sigmoidea, donde el crecimiento inicialmente es exponencial (aumenta en un constante porcentual en función del tiempo), transcurrido un determinado tiempo se ralentiza (la tasa de crecimiento disminuye) y finalmente, en la madurez, se detiene. Este comportamiento se observa en las curvas de crecimiento que se presentan en la figura 1 , donde a la fase de aceleración rápida le sigue una fase de menor tasa de crecimiento -a medida que el animal se aproxima al peso adulto (peso asintótico) - y posteriormente una fase de estabilización del peso corporal, correspondiente al peso adulto.

En relación con el comportamiento de los parámetros (Tabla 2), se observa que la fase de crecimiento exponencial aumenta con el peso adulto estimado por el modelo (a), presentando mayores valores para el parámetro $x_{0}$. El análisis de correlación de Spearman evidenció la relación directa y significativa que existe entre los parámetros a y $x_{o}(r=0.6959$, $\mathrm{p}<0.05)$. Entre las funciones de crecimiento con comportamiento sigmoidal, la ecuación logística fija el punto de inflexión exactamente al $50 \%$ del peso a la madurez del animal (9), lo cual explica la relación directa que se registró entre los parámetros a y $x_{0}$. A diferencia de los resultados del presente trabajo, donde la correlación entre los parámetros $a$ y $1 / b$ no fue alta ni significativa $(-0.32, p=0.3642)$, Malhado et al (10) en experimento con bufalinos, encontró que la correlación entre estos parámetros fue alta (-0.71), cuya interpretación biológica es que animales con mayores tasas de crecimiento tienen menor probabilidad de alcanzar mayores pesos en la madurez, comparados con aquellos que crecen más lentamente en el inicio de la vida. Sarmento et al (11) resalta que esta relación, biológicamente, es la más importante. El inverso del parámetro $b(1 / b)$ refleja una tasa relativa de crecimiento durante

\section{DISCUSSION}

The logistic curve models the sigmoid function, where growth is initially exponential (increases by a constant percentage depending on time), after certain time slows down (growth rate decreases) and finally, in maturity, stops. This behavior is observed in the growth curves showed in figure 1 , where the rapid acceleration phase is followed by a phase of lower growth rate - as the animal approaches its adult weight (asymptotic weight) - and then a stabilization phase of the body weight, corresponding to the adult weight.

In relation to the behavior of the parameters (Table 2), it is observed that the exponential growth phase increases with the adult weight estimated by the model (a), showing higher values for the parameter $x_{0}$. The Spearman's rank correlation analysis showed the direct and meaningful relationship that exists between the parameters $a$ and $x_{0}(r=0.6959, p<0.05)$. Between growth functions with behavior sigmoidal, the logistic equation sets the turning point exactly at $50 \%$ of the mature weight of the animal (9), which explains the direct relationship recorded between parameters $a$ and $x_{0}$. In contrast to the results of this study, where the correlation between parameters $a$ and $1 / b$ was neither high nor significant $(-0.32, p=0.3642)$, Malhado et al (10) in an experiment with buffalos, found that the correlation between these parameters was high (-0.71), whose biological interpretation is that animals with higher growth rates are less likely to reach higher weights at maturity, when compared with those that grow more slowly in the beginning of their life. Sarmento et al (11) highlights that this relationship, biologically, is the most important. The inverse 
la fase exponencial, que para el modelo logístico es antes de lograr el $50 \%$ del peso asintótico, es decir antes del punto de inflexión. En las tablas 1 y 2 se observa que el tiempo en que se iniciaron las mediciones del peso corporal superó el parámetro $x_{0}$ para las razas York Shire Terrier, Teckel y Beagle, lo cual ilustra la falta de datos durante esta fase exponencial, comprometiendo los resultados de $1 / b$ para las razas en mención.

Case et al (2) confirman la menor duración del período de mayor velocidad de crecimiento en razas pequeñas, que termina alrededor de los 3 meses de edad, en tanto que en razas grandes y gigantes, el crecimiento exponencial se puede prolongar por 1 y 2 meses más, respectivamente. Como norma empírica, los perros de tamaño pequeño y mediano (peso adulto hasta los $25 \mathrm{Kg}$ ) alcanzan alrededor del $50 \%$ de su peso adulto aproximadamente a los 4 meses de edad y aquellos con peso superior a $25 \mathrm{Kg}$, alrededor de los 5 meses de edad. Este concepto coincide con los resultados del presente trabajo, donde las razas pequeñas, medianas y grandes exhibieron un valor medio para el parámetro $x_{o}$ correspondiente a $3.49 \pm 0.03$, $4.21 \pm 0.42$ y $5.27 \pm 0.86$ meses, respectivamente (media+desviación estándar).

De los resultados del presente trabajo se concluye que la duración del período de crecimiento de los perros depende del tamaño del animal. Las razas de perros grandes alcanzan la madurez mucho más tarde que las razas de perros pequeños. El $99 \%$ del peso corporal adulto $\left(T_{99}\right)$ para las razas pequeñas, medianas y grandes fue alcanzado en promedio a los $9.46 \pm 1.63,12.52 \pm 0.61$ y $14.37 \pm 1.79$ meses, respectivamente (media+desviación estándar). Estos hallazgos coinciden con las indicaciones dadas por Case et al (2), referidas a que la madurez (tamaño adulto) se alcanza entre los 10 y 16 meses de edad para las razas grandes y entre los 6 y 12 meses de edad para las razas más pequeñas.

Con base en el concepto general referido a que la curva de crecimiento se estabiliza al año de edad, la mayoría de los fabricantes de alimentos y profesionales del sector recomiendan que el alimento para cachorros se garantice hasta ese momento, no obstante, es importante resaltar que este concepto sólo se aplica para cachorros de razas medias. Al tratarse de razas grandes o gigantes será necesario extender el aporte de nutrientes para cubrir las demandas de crecimiento por un período adicional, lo cual fue matemáticamente evidenciado a partir de los parámetros del modelo logístico empleado para el análisis de los datos del presente trabajo. De acuerdo con el NRC (4), las razas medianas, grandes y gigantes alcanzan el 95,88 y $80 \%$ del peso maduro $(20,35$ y $60 \mathrm{Kg}$, respectivamente) a los 12 meses de edad. Las guías of the parameter $b(1 / b)$ reflects a relative growth rate during the exponential phase, which for the logistic model is before reaching $50 \%$ of the asymptotic weight, i.e. before the turning point. Tables 1 and 2 show that the moment when body weight measurements began exceeded the parameter $x_{o}$ for the York Shire Terrier, Dachshund and Beagle breeds, which illustrates the lack of data during the exponential phase, biasing the results of $1 / b$ for the breeds mentioned.

Case et al (2) confirmed the shorter duration of the period of faster growth in small breeds, which ends at around 3 months of age, while in large and giant breeds, the exponential growth may be extended in 1 and 2 months, respectively. As an empirical rule, small and medium-sized dogs (adult weight up to $25 \mathrm{Kg}$ ) reached around $50 \%$ of their adult weight at approximately 4 months of age and those with a weight over $25 \mathrm{Kg}$, at about 5 months of age. This concept coincides with the results of this study, where small, medium and large breeds exhibited a mean value for the parameter $x$ corresponding to $3.49 \pm 0.03$, $4.21 \pm 0.42$ and $5.27 \pm 0.86$ months, respectively (average + standard deviation).

From the results of this study it is concluded that the duration of the growth period of dogs depends on the size of the animal. Large dog breeds reach maturity much later than small dog breeds. Ninety-nine percent of the adult body weight $\left(T_{9 g}\right)$ for small, medium and large breeds was achieved on average at $9.46 \pm 1.63$, $12.52 \pm 0.61$ and $14.37 \pm 1.79$ months, respectively (average+standard deviation). These findings are in line with the indications given by Case et al (2), concerning that maturity (adult size) is reached between 10 and 16 months of age for large breeds and between 6 and 12 months of age for smaller breeds.

Based on the general concept that the growth curve stabilizes at one year of age, most food manufacturers and industry professionals recommend guaranteeing puppy food until that time, nevertheless, it is important to highlight that this concept is only applicable to medium breed puppies. When dealing with large or giant breeds it will be necessary to extend the supply of nutrients to meet the growth demands for an additional period, which was mathematically evidenced from the parameters of the logistic model used for the analysis of the data of this study. According to the NRC (4), medium, large and giant breeds reach 95,88 and $80 \%$ of their mature weight (20, 35 and $60 \mathrm{Kg}$, respectively) at 12 months of age. Nutritional guidelines, as well 
nutricionales, así como los profesionales y personal responsable de la tenencia de mascotas deben orientar los planes de manejo (alimentación y actividad) a partir del conocimiento de las curvas de crecimiento que caracterizan las diferentes razas, que aunque sean de tamaño similar presentan diferencias en los parámetros estimados, como se evidenció en el presente trabajo. Es reconocido que la velocidad de crecimiento aporta información valiosa sobre riesgos nutricionales asociados, a saber, obesidad y enfermedad ortopédica del desarrollo, de común presentación en animales de compañía.

En el presente trabajo, el modelo logístico se mostró adecuado para describir el crecimiento en perros de diferente tamaño, no obstante, un mayor tamaño muestral mejorará su capacidad predictiva, dada la variabilidad individual que caracteriza el crecimiento. as professionals and personnel responsible for pet ownership, must guide the handling plans (feeding and activity) from the knowledge of the growth curves that characterize different breeds, which albeit of similar sizes have differences in the parameter estimated, as evidenced in this study. It is recognized that the growth rate provides valuable information about the associated nutritional risks, namely obesity and developmental orthopedic disease, common in pets.

In this study, the logistic model was appropriate to describe the growth of different-sized dogs, however, a larger sample size will improve its predictive capability, given the individual variability that characterizes growth.

\section{REFERENCES}

1. Trangerud C, Grøndalen J, Indrebø A, Tverdal A, Ropstad E, Moe L. A longitudinal study on growth and growth variables in dogs of four large breeds raised in domestic environments. J Anim Sci 2007; 85:76-83.

2. Case LP, Carey DP, Daristotle L, Hayek MG, Raasch MF. Development and Treatment of Obesity. Canine and Feline Nutrition, 3th edición. USA: Mosby Elsevier; 2011.

3. Hawthorne AJ, Booles D, Nugent PA, Gettinby G, and Wilkinson J. Body-Weight Changes during Growth in Puppies of Different Breeds. J Nutr 2004; 134:2027S-2030S.

4. National Research Council -.NRC. Nutrient requirements of dogs and cats. 1a ed. Washington, D.C: National Academy Press; 2006.

5. German AJ. The Growing Problem of Obesity in Dogs and Cats. J Nutr 2006; 136:1940S-1946S.

6. Ulloa JTI, Rodríguez JAC. El modelo logístico: Una alternativa para el estudio del crecimiento poblacional de organismos. REDVET [en línea] 2010; [fecha de acceso 15 de septiembre de 2013]; 11(3). URL disponible en: http:// www.veterinaria.org/revistas/redvet/ n030310/031004.pdf
7. American Kennel Club. AKC Breeds complete breed list. [en línea] AKC: 2012; [acceso 30 de septiembre de 2013]. URL disponiblen en: http://www.akc.org/breeds/complete_ breed_list.cfm

8. SAS/STAT: User guide version [programa de ordenador]. Versión 9.1.3. Cary (NC): SAS Institute Incorporation; 2003.

9. Kuhi HD, Porter T, Lopez S, Kebread E, Strathe $A B$, Dumas A, Dijkstra J, France J. A review of mathematical functions for the analysis of growth in poultry. World Poultry Sci J 2010; $66: 227-240$.

10. Malhado CHM, Ramos AA, Carneiro PLS, Souza JC, Wechsler FS, Eler JP, Azevêdo DMMR, Sereno JRB. Nonlinear models to describe the growth of the buffaloes of murrah breed. Arch Zootec 2008; 57:497-503.

11. Sarmento JLR, Regazzi AJ, Souza WH. Estudo da curva de crescimento de ovinos Santa Inês. Rev Bras Zootec 2006; 35:435-442. 